\title{
From municipal feminism to the Equality Act - Legislation and gender equality work in UK local government 1980-2010
}

Women's Studies International Forum 66 (2018) 1-8

\section{Freya Johnson Ross}

UCL Institute of Education 36 Gordon Square, London, WC1H OPD, United Kingdom

\section{Abstract}

For decades local government has been an important site for the development of gender equality practice, and the implementation of legislation attempting to address inequality in the UK. The rise of 'municipal feminism' during the 1980s marked a particular instantiation of gender equality work. Yet at the time the relationship between this phenomena and legislation was not given significant attention. The Equality Acts of 2006 and 2010 have been key milestones for local government gender equality work subsequently, yet little work has considered the detail of their implementation at the ground level by council employees. This article contributes to addressing this gap by examining the influence of legislation on local government gender equality practice at this level, and how this has changed over three decades. It draws on findings from a comparative historical study of three sites within the UK.

Keywords: Gender equality, Municipal feminism, Local government, Legislation, Equality Act, Gender Equality Duty

Introduction

Post-feminist narratives - positioning gender equality as achieved, and women in particular as the bearers of opportunity - can suggest the very existence of gender equality legislation 
means this inequality has been addressed. Thus, it can seem that legislation (such as the Equality Acts) represents the end of a process. In reality, the significance of legislation depends on its implementation. Nor is its permanence guaranteed, indeed, immediately after the 2010 Equality Act was passed, the extent to which it would be brought into force was uncertain, and more recently the 2013 government's Red Tape Challenge placed its status in question. This has also been borne out in other European contexts such as Finland (Holli, Luhtakallio et al. 2006), and raises the question of the longer historical trajectory of gender equality work within specific institutional contexts. The theorisation of post-feminism (McRobbie 2004, Gill 2007, McRobbie 2007, 2009), in conjunction with the rise of neoliberalism (Brown 2003, Walkerdine 2003, Thorsen and Lie 2006) and shift towards new public management (Leach and Barnett 1997, Newman 2000, Swann and Fox 2010) are significant contextual developments in thinking through the evolution of local government gender equality work between 1980 and 2010. Councils in the UK must respond to this legislation as public bodies. They have also been important sites for the development and practice of work on gender equality - in terms of internal organisation and working practices, and externally provided projects and services (Lovenduski and Randall 1993). This article contributes to addressing a gap in the literature by scrutinising the practical enactment of gender equality legislation by professional workers, at the level of local government, over the trajectory between municipal feminist working of the 1980s, and the present day.

Following the literature review, and presentation of my methodology, I argue for the increasing significance of legislation in shaping local government gender equality work and the standardising influence of the Gender Equality Duty. Alongside this I suggest the distinctions between the three sites evidences the space of interpretation around this, where the knowledge and understanding of individual equalities workers is key to its enactment. I highlight knowledge and understanding of gender equality, and not just related legislation, as a potential vulnerability in the quality and sustainability of this process. Lastly, I discuss the implications this has for the definition and prioritisation of gender and other equalities work in 
light of the Public Sector Equality Duty. I suggest that this is valuably considered alongside the specific institutional histories of gender equality work in seeking to understand this process.

Mapping the field

The 1980s saw a notable rise in specific local government initiatives addressing women's rights. This work on gender equality, or 'municipal feminism' as it was coined, represented a particular instantiation of feminist activity among others, although it has generally been underplayed in the literature examining this (MacKay 2008). At the time such work was contested as opposed to universally welcomed - both by other feminists (Coote and Pattullo 1990, Halford 1990), and those within councils (Button 1984, Stokes 1998). Although this phenomena received some academic attention at the time (for example, Button 1984, Goss 1984, Edwards 1988, 1989, Harriss 1989, Brownill and Halford 1990, Halford 1990, 1992, Bruegel and Kean 1995, Edwards 1995), this was largely focused on documenting the establishment, topics and form of work taking place, and discussing its political dynamics and significance. Although certain political figures involved came to public prominence in part through media coverage, such as Valerie Wise in London, the present study focuses specifically on the non-elected council workers involved across the UK. Research at the time was also positioned within broader debates at the time about gender, organisation(s) and the state (Watson 1991, Witz and Savage 1991). Historically, the theory and praxis of the relationship between feminism and the state has been a significant and fundamentally ambivalent area. Ranging from a wholesale rejection of the state as a site for productive engagement or action, to more statist or nuanced accounts (Rowbotham 1979, Franzway, Court et al. 1989, Rowbotham 1996, Randall 1998, Kantola 2006, Chappell 2013). There has also been a significant body of work examining 'state feminism' where states are seen to act in a quasi-feminist manner (Mazur and Stetson 1995, McBride and Mazur 2010), which 
continues to evolve (for example, Kantola and Squires 2012). Yet this literature is usually at the level of the nation state rather than federal level, and focusing on the political rather than micro level processes at play within an institution. There has not been much work subsequently that has examined municipal feminism, nor in relation to more recent local government gender equality work. Notable exceptions are Stokes (1998), and Bashevkin (2006) who examined the legacy of municipal feminism in London and Toronto. Thus, the relationship between municipal feminist initiatives and gender equality legislation has not been fully examined. This is significant, particularly as Edwards (1989), and Coote and Pattullo (1990) pointed out, legislation directly supporting their work would have helped to legitimise their sometimes controversial endeavours. Edwards also discussed how preexisting legislation on equality and employment made work on this particular area easier. Although the literature on municipal feminism touches upon it, there is little specifically considering the role of legislation in driving and shaping the work of municipal feminist initiatives.

Some scholarship has connected the development of women's initiatives to broader changes and legislation on gender equality. This discussion was already taking place during the period in which the initiatives were being established — for example Coyle (1989) and Lovenduski (1989) mention the role that local government played as an innovator in the equality field. Lovenduski and Randall (1993) also suggested the achievements of municipal feminist women's initiatives included legitimising the discussion of the gender dimensions of council policy and practice.

Alongside this, the past decade has seen several significant pieces of legislation specifically addressing gender equality, with particular implications for local government. There has been some research examining these developments (for example, McLaughlin 2007, Squires 2009) and related institutions (Lovenduski, 2007), including the 2010 Equality Act and Public Sector Equality Duty (Fredman 2011, Hand, Davis et al. 2012, Squires and 
Hermanin 2012) focusing on their legal and theoretical implications, as opposed to their implementation in practice, and considering this within the wider European context, at national level. Little work discusses this in relation to gender and local government however - with Conley and Page (2010), Monro (2006), and Richardson and Monro (2013) notable exceptions. Richardson and Monro's article considers the views of practitioners, but focusing on sexualities rather than gender. These authors raise important questions about its utility and operationalisation also discussed earlier by Halford and Leonard (2001), as for example, what an organisation says it does can differ from what it carries out. Relatedly, Callerstig (2014) examined the implementation of gender mainstreaming in public sector organisations in Sweden, providing insights into the central role different actors play in this process. This article builds on this, making an original contribution through a comparative analysis - over time and between sites - focusing on the role of legislation (including specific duties) at the practical level of UK local government gender equality work.

\section{Methodology}

To examine the significance and enactment of legislation over time, I utilised a mixed qualitative method with a comparative element. I constructed a sample of three sites of local government; categorised as the 'pioneering', 'enthusiastic follower', and 'late adopter' councils, based on the time period in which they first developed their women's initiative. This drew on work by Halford (1990) mapping the occurrence of municipal feminism in the UK. The selection was designed to represent a spread of the national political and organisational conditions of the period for the inception of the initiatives, while maintaining similar urban socio-political conditions across all three. The pioneering council was and remains a Labourled borough council in London, which formed its women's initiative at the start of the 1980s. The smallest of the sites, its population was and remains ethnically diverse, with high levels of deprivation. The enthusiastic follower council was a Labour and later Liberal Democrat-led 
city council in the South-West, which formed its women's initiative in the mid-1980s. It is larger, though less ethnically diverse and relatively less deprived than the pioneering council. The late adopter council was and remains Labour-led, a city council in the North, which did not develop its women's initiative until the beginning of the 1990s. It has the largest in terms of population, the least ethnically diverse, with levels of deprivation between those of the other two sites.

In each site I undertook semi-structured interviews (lasting approximately an hour) with six gender equality workers within the council - current (2011) and from the period of the initiatives' inception. The contemporary interviewees were selected following negotiation with gatekeepers, and identification of those with most oversight of gender equality. Using archival records from each site, the names of the initial staff members were identified before being approached to participate. Comparable texts relating to the councils' gender equality work were collected at each site for both periods (including policy texts, reports, job specifications, impact assessments) - following searches in local archives and council records, and insights from interviewees. All texts and interviews were transcribed in full and analysed using NVivo. Utilising texts and interviews enabled the triangulation of sources, as well as facilitating the examination of the way in which ideas about gender equality are articulated through legislation, policy and the actors responsible for this. The historical comparative dimension was valuable as it enabled the examination of the relationship between legislation and gender equality working over time - something which has not usually been the case in research on this topic.

In analysing the data I drew insights from hermeneutic approaches that can encompass both the interpretive, experiential and material (Cerwonka and Malkki 2007), as well as those focused on discourse (Parker 1992, Allan 2008). These are useful in recognising both the constructed and constituting nature of 'talk' about gender equality, and the need to consider this talk in its broader institutional, historical and socio-political context when seeking to 
understand it. Central concepts for my analysis were Connell's account of gender (2002); which regards it as a multi-dimensional set of relationships structuring social relations, yet with practice central to its production and change. Lombardo, Meier, and Verloo's account of the discursive politics of gender equality (2009) was also a key referent. This recognises the significance of (dynamic) discursive framings of gender equality for policy enactment; the way in which the notion of gender equality can undergo processes of shrinking, fixing, stretching and bending as policy and legislation is created and implemented. These provide a constructive framework through which to consider the changing significance, understandings and implementation of gender equality legislation in local government.

The varying significance of legislation for the municipal feminist initiatives

Examining the municipal feminist era texts from my sites suggested the pioneering council's initiative was most conscious of legislation in its working, and the late adopter's the least. The late adopter council initiative was formed at the beginning of the 1990s, without the status nor resources of a full committee. There is only one explicit mention of legislation in the documents examined from the late adopter council, where its 1991 policy statement on women and equality says:

legislation alone has not and will not, result in equality for women and that many changes in societal responsibilities and attitudes are required before women will have real equality of opportunity.

The emphatic 'has not and will not' suggests a perspective not entirely convinced of the utility of legislation as a driving factor in equality, seeing external, 'societal responsibilities and attitudes' as needing to lead, rather than legislation, or indeed local government. There 
is also no reference to any specific pieces of legislation relating to equality, although the notion of 'equal opportunity' (as opposed to outcomes or other measures) arguably reflects the notion codified earlier in the 1975 Sex Discrimination Act, which established the Equal Opportunities Commission. It is perhaps unsurprising then that legislation is also not referenced in relation to the planning or execution of the initiative's work.

We might have expected the late adopter council, given its timing, would have taken the opportunity to learn from earlier initiatives, including their use of legislation to legitimise their working - something Edwards suggested at the time regarding race equality (1989). However, this does not appear evident, and instead the reluctance of the council to create a women's initiative - as recounted in interviews with workers, and reflected in its form - is also borne out in the somewhat resigned attitude reflected in its documents. As Halford discussed in her work on women's initiatives, this could reflect the old-guard nature of the Labour Party in the late adopter authority (Halford, 1990). In contrast to the other sites, the interviews at the late adopter council do not add significantly to our understanding of how legislation related to its gender equality work. One interviewee recounted discussing legislation at NALGWC (the National Association of Local Government Women's Committees) meetings. NALGWC was a significant membership forum for women's initiatives at the time, providing a regular conference space where both councilors and workers from around the UK would come together to share knowledge and ideas, as well as mutual support. It also provided a channel for sharing information between initiatives. However, this brief mention of legislation did not appear to reflect its wider importance in the local context of the late adopter initiative.

The enthusiastic follower initiative was formed several years after the first initiatives, and endowed with a fairly high level of status and resources. There were more frequent references to legislation in its documents. For example, the 1986 job descriptions for the unit's workers require the appointee, 'maintain an up to date knowledge of relevant 
legislation'. This suggests from its inception it was envisaged legislation would be integral to shaping the unit's work, through its staff. This also introduces the idea of equalities knowledge, specifically regarding legislation, as a key professional capacity of the workers and central to shaping its enactment. The interviews also evidenced a slightly increased concern with legislation compared to the late adopter initiative. However, this was partly about the way the national Labour Party developed equalities legislation (chiming with the concern with democratisation it was undergoing (Halford, 1990)) rather than the way this shaped council practice.

The pioneering council showed the greatest concern with equalities legislation for its working. As in the enthusiastic follower, the 1982 job description for the initiative's women's officer includes the requirement, "to advise on the implications of existing and future legislation in the area of women's equality', making it clear this knowledge was a core skill for an employee. There are also several points suggesting the initiative was enacting work in response to legislation, particularly regarding employment both internal and external to the council. For example, the 1989 progress report of the women's committee recounts:

following the 1984 equal value amendment to the equal pay act, [the council] initiated research into how the amendment would affect local authorities as employers. This lead to a broader study — co-ordinated by [the council] — which has now provided local authority employers with the information they need to incorporate the principles of equal pay for work of equal value into their own pay structures.

This shows the pioneering initiative responding to legislation through undertaking research, proactively using this to inform practice, and sharing this work with other employers. This also supports Edwards' (1989) suggestion that work on employment was easier for women's initiatives to undertake as this was already legislated for. We might then hypothesise that as legislation developed over time, it would facilitate broadening work on equalities in local 
government. The interviews supported the view that legislation was at the forefront of the women's initiative's development, as all interviewees felt it was significant for their working. Speaking about the development of the initiative Geraldine said:

I think it was a direct response to a lot of what the GLC was doing at the time and the legislative framework around equalities, particularly the Sex Discrimination Act...the council was very progressive in terms of wanting to move the equalities agenda into both employment and service delivery. (Geraldine, Women's Unit Worker, Pioneering Council)

This enunciates the idea that the very existence of the women's unit in the pioneering council was partly in response to national equalities legislation. It also highlights the significance of the GLC, and its high profile women's initiative led by Valerie Wise in inspiring other work in this area. The interview data from the council also arguably reflects its staff using legislation as a lever for change, both within and outside the council. Legislation was being used within the strategic framing of council business to work to support gender equality. This was discussed in relation to housing, childcare and employment. One interviewee described being influenced by the GLC's use of contract compliance to embed equalities into the council's working. This was a means through which the council could use its position not just as an employer, but as an organization tendering contracts to much wider numbers of employees, to improve the conditions of workers - essentially by specifying minimum standards for their employment in their contractual arrangements. For example in relation to hiring practices, pay or conditions. Another recounted:

a woman wanted to be rehoused and it was members that really, the women members that picked up, although this was a child protection issue, it was a gender issue as well because it was women that tended to be the main carers. And so we used the 
children's act to try and highlight the need to improve rehousing policies. (Geraldine, Women's Unit Worker, Pioneering Council)

This is striking as it suggests an astute and active relationship with the national legislation that was not present in the other two sites, with the employees stretching legislation on children in order to allow them to address gender equality, and see the connections between these. This also highlights the importance of the individual actors in enacting legislation without whose knowledge and skills its significance is limited.

Comparing the three sites, the texts and interviews suggest significant variation between the councils in their relationship with national equalities legislation. This appeared most important in driving and shaping the working of the pioneering council's initiative, followed by the enthusiastic follower, and lastly the late adopter. There are various factors we might posit influencing this. Considering the broader political environment and the time at which the initiatives were formed, the pioneering initiative was created during a period of antagonism between national and local government - perhaps meaning legislation was more important in bolstering its work. Whereas, following the abolition of the GLC, the late adopter council's development of an initiative might have been less controversial. It could also have been that the physical distance of the councils from the seat of national government influenced their attentiveness to legislation, as the pioneer was in London, and the late adopter geographically the furthest away. For the present comparative historical analysis, the lack of standardisation between the councils in relation to legislation is itself notable - partly revealing the discursive space of enactment surrounding it. This has also shifted significantly over the ensuing three decades, evident as we now move to consider the contemporary working of the councils. It's also valuable to recognise the multiplicity of factors which shape councils' policy and work on gender equality, including the possible influences of local stakeholders, both solicited and unsolicited. Although this article focuses on the significance of national legislation, and the internal actors responsible for carrying this 
out within council organisations, in both periods the attention and interests of local people or service users were invoked in different ways (which I have discussed in more detail elsewhere). Although beyond the scope of the present article, whether framed as 'democratisation' and a reconfiguration of the council's operating proceedures duing the municipal feminist period, or as 'consultation' and 'needs assessment' more recently, attending to the public, or at least appearing to, appeared present in the constellation of factors presented as shaping the council's working.

The significance of legislation for contemporary gender equality working

Collecting contemporary data in 2011 from the same councils enabled consideration of how the relationship between the local government working and national gender equality legislation has changed over time. I considered this particularly in relation to the Gender Equality Duty (which came into force in 2007), and Public Sector Equality Duty (which came into force in 2010) due to their specific requirements for councils. Conley and Page suggest that, overall, the ideological underpinning of equalities has shifted from a social justice, institutional framework, to a business case around mobilizing individual difference (Conley and Page 2010).

As well as these legislative developments, there have been other significant contextual changes shaping the environment for local government. Politically, the Conservative central government of the late 1980 s and 1990s drove to curb the power of local government (Travers 1990) - exemplarised by abolition of the metropolitan county councils, including the Greater London Council in 1986. Yet the actual impact of the restructuring of local government has been debated (Leach and Davis 1990). Relatedly, the Conservative party oversaw the removal of councils' ability to set their own rates for revenue and restrictions on capital spending (Gibson 1992). The Labour central government's agenda from 1997 to 
2010 also included continuing the strengthening of performance and inspection culture, and an emphasis on strong leadership and move towards executive government at local level (Leach 2010). Broadly, many of the changes to the organization and management of public sector working by both political parties over this period have come to be analysed as new public management (Leach and Barnett 1997, Newman 2000, Swann and Fox 2010). Not uncontroversially, this involves a greater focus on efficiency and outcomes, applying ideas previously associated with the private sector. The rise of performance management and indeed the shift to frame equalities in administrative rather than political terms (Monro 2006) have been important in shaping local government gender equality working since the women's initiatives were created. This forms the backdrop against which these specific pieces of legislation have been implemented.

The documents from all three council sites evidence a much higher frequency of reference to legislation compared to the earlier period. For example, the pioneering council's gender equality scheme for 2011 to 2014 explicitly states:

we will put the gender equality duty into practice to ensure that men and women living or working in [the council] are treated fairly and have equal opportunities.

This directly reflects the wording of the Gender Equality Duty and the dimensions to address both the council's workforce and delivery of services it requires. Similarly, the 2011 annual report on equalities and community cohesion from the enthusiastic follower council explains what the Duty requires, and outlines its strategic aims to achieve this. The documents from all three sites discuss their work to fulfill the Gender Equality Duty — including carrying out equality impact assessments, gathering data, planning, monitoring and reviewing policies and services in relation to equalities. In comparison to the initial working of the equalities initiatives - the increased standardisation of the councils in their work with reference to gender equality legislation is evident. Conley and Page (2010) previously suggested that the 
Gender Equality Duty was not seen as the primary driver for work in this area. My data builds on this by evidencing the 'levelling' impact it has had: there is a much clearer common approach between the councils in the action being detailed, reflective of the requirements of the Duty. This aligns with Hermanin and Squire's (2012) examination of anti-discrimination policy at a European level - where they suggest a degree of alignment between nation states has resulted.

The 2010 Equality Act and related duty combined a range of different pieces of legislation, and nine protected characteristics, where historically in the UK race, gender and disability have taken priority in legal terms (Lovenduski 2007, Squires and Hermanin 2012). These are: age, disability, gender reassignment, pregnancy and maternity, race, religion and belief, sex, sexual orientation, and marriage and civil partnership. If we consider this in relation to Lombardo et al's notion of the discursive politics of gender equality, we might suggest 'gender equality' as a category in itself no longer exists, or has been shrunk. However, constituent elements of a broad conception of gender (Connell 2002) remain: sex, gender reassignment, pregnancy and maternity, sexual orientation, and marriage and civil partnership. So conversely, to what extent might connections be enabled between these, considered intersectionally or indeed structurally? I return to these questions later.

All three sites at least mention the 2010 Act in their equality documents. However, the sites reflect different levels of integration of their work across the nine strands of the Act. The enthusiastic follower has the most integrated documents, while the pioneering council retains separate equality schemes as well as some combined reporting on the equality strands. The late adopter has integrated race, gender and disability schemes (in line with the pre-2010 Equality Act duties), as well as maintaining separate equality schemes, thus reflecting the priorities seen in earlier iterations of UK equalities legislation focused on these three areas. On the one hand we can see the increased reference to legislation comparing the texts from all three sites between time periods, and significant standardisation of this in 
relation to the Gender Equality Duty. However, there remains variation between them, particularly in relation to the translation of the Public Sector Equality Duty into these documents - highlighting the discursive space at this stage of implementation. Additionally, it appears that the level of engagement the councils had with legislation during the earlier period has been mirrored to some extent in the latter - as reflected in their structuring of the different equalities strands in their texts. The late adopter council has continued to be the least responsive to the most recent legislative changes. The early adopter and enthusiastic follower have in some sense shifted places, but remain relatively engaged as before. This suggests the institutional history of gender equality work - indeed a dimension of path dependency (Thelen, 2004) - is significant in this local government context of legislative enactment; as I have discussed elsewhere, rooted in the organizational position and form of the initial women's initiatives.

Practitioners' reflections on contemporary gender equality legislation

The articulation of legislation and policy into plans and practice is a significant process, with space between legislative commitments being written into policy texts, and what is then enacted. The accounts of the individuals involved in this at local government level provide us with valuable insights into the process of this enactment in the UK; how gender equality is stretched, bent, shrunk and fixed as legislation is put into practice. Across all three councils the current equality workers I interviewed suggested that recent legislation had been significant in shaping their work on gender equality, as something generative and selective. For example, it was suggested posts had been developed in response to legislation, as one interviewee explained, 'as legislation developed, then more posts were created' (Jenny, Principal Equalities Officer, Enthusiastic Follower Council). 
Legislation was also seen to play a role in prioritising work on different equality strands, as one interviewee discussed:

we went from specific equality units to all equality brought together, there was when I took over a definite hierarchy of importance. (Eleanor, Head of Policy, Partnerships and Performance, Pioneering Council)

Eleanor went on to suggest the incremental introduction of legislation had provoked this hierarchy; with race being prioritised over gender, over the other strands. This suggests similar patterns are evident at local as at national level as seen in Squires and Hermanin's (2012) work. Other interviewees also explained how legislative changes had widenened the topics they worked on, for example to include men - reflecting a stretching of the space of gender equality work.

It was also clear that for the equality workers, knowledge and understanding of equalities legislation, and related technical skills were a key professional capacity. As one interviewee in the enthusiastic follower council emphatically recounted:

Gone are those days where you could just be an activist transplanted into the council. You've got to be blinkin' good on legislation, you've got to be good on data analysis because you know you've got to be evidence based and scientific. (Dot, Equalities and Community Cohesion Manager, Enthusiastic Follower Council)

Arguably the increased reference to knowledge of equalities legislation itself serves as a marker of the central role legislation plays for workers. In this case, knowledge of legislation is regarded as crucial to being able to communicate and enact equality work in the context of the contemporary council - illustrating a dimension through which the workers shape the 
discursive space of gender equality. Yet as I discuss further later, this is distinct from knowledge and understanding of gender equality per se.

The interviewees also revealed the way in which topics and techniques of work were being employed specifically reflecting the requirements of the Gender Equality Duty and Public Sector Equality Duty. Particularly, work on equal pay, equality impact assessments, and monitoring and reporting on equality - reflecting a significant standardisation across the three sites. For example, the rise of monitoring and reporting on gender equality, and how work has subsequently developed was raised by Eleanor at the pioneering council:

I think prior to that [2006] it was quite hard to show that there was equality of outcomes because it wasn't always monitored.

Another interviewee explained the positive impact of having to plan and report on equalities work and its outcomes. Fran suggested although some of the recommendations made in legislation were already, 'in place', a positive effect had been the resulting focus on achievable outcomes - as opposed to unattainable goals. As action plans developed there was a realisation that, 'you can't always do everything' (Fran, Senior Planning and Social Work Officer, Late Adopter Council). This standardising effect was also reflected by an interviewee from the pioneering council reporting that, although the council's equality work pre-dated the legislation, legislation had concentrated their energy on certain areas of this pre-existing work like equal pay. My interview data thus builds on the analysis of the councils' texts: showing the significance of legislation and standardising influence of the Gender Equality Duty, and evidencing the knowledge and skills this requires of workers.

The central positives interviewees reflected had been drawn from the Gender Equality Duty were its utility for gaining organizational commitment to clear goals, and being able to hold others to account on this. As one interviewee explained: 
it can be quite useful if you're trying to get commitment corporately here, if you say it's a legal requirement, it tends to focus people's minds (Antony, Human Resources Manager, Pioneering Council)

Another interviewee added:

god, life became so much easier with the equality legislation...I think it's made a profound difference just in terms of the ability to hold people to account. You could never hold people to account before and you can now. (Martha, Women's Forum CoChair, Enthusiastic Follower Council)

This interviewee explained the way in which work had taken place to influence the council to address specific issues of policy and practice, such as the licensing of sexual entertainment venues, using equality legislation. This moves beyond Conley and Page's (2010) finding that the Gender Equality Duty played a role in legitimising work, and suggests a constructive alignment between performance management and gender equality goals.

Although early days in its implementation, the interviewees also reflected positively on the simplification and unification of equalities strands in the Public Sector Equality Duty. One explained:

that was long awaited, we had to have everything brought together to have a bit of a level playing field really for all the equality characteristics, so in that respect [the Equality Act was] very helpful. (Eleanor, Head of Policy, Partnerships and Performance, Pioneering Council) 
Another interviewee from the enthusiastic follower council described the 2010 Act as a gift; harmonizing and easier to understand. They went on to discuss the role the Act had played in reducing the hierarchy of importance between the different equality strands, and work which was being undertaken in relation to linking two of the stands, race and age, in order to work on new areas. In the late adopter council too, the Head of Equalities emphasised the welcome legislative simplification - again motioning to the technical knowledge required of workers to navigate legislation, and enact it productively.

Alongside these positive elements reported, there were also notable points of ambivalence surrounding legislation's implementation. These included: time costs of processes such as impact assessments, challenges with related technical requirements, and difficulty justifying work specifically with women. The interview data makes clear the move towards a more strategic and technical approach to work - prompted in part by the legislation. Although this had benefits, interviewees also explained challenges - for example how equalities impact assessments could be undermined by the depth of knowledge and understanding nonspecialist staff need to satisfactorily complete them. Jenny suggested that many, 'haven't the foggiest idea of what they are supposed to be writing' (Jenny, Principal Equalities Officer, Enthusiastic Follower Council), which could lead to confusion over their purpose.

The role of impact assessments and related data analysis in shaping what is prioritised, carried out, and measured is complex. It provides a site where legislative requirements and techniques of new public management come together with the knowledge and skills of equality workers - and ultimately shapes what is enacted. As a very experienced interviewee explained:

equalities impact assessments and this data analysis has made it harder for us to justify sustaining a gender equality agenda, because women on the face of it don't 
have as high needs as some of the other equalities communities. (Jenny, Principal Equalities Officer, Enthusiastic Follower Council)

She went on to explain how this led to undertaking ever more complex data analysis, overlaying multiple factors and characteristics to provide justification for examining the conditions under which women live. For example, in seeking to retain specialist women only services in the city, the workers at the Enthusiastic Follower Council had increasingly needed to use data, and specifically segment it in relation to different characteristics, in order to make the case that women remained worthy of these services, and crucially funding. In Jenny's experience few local authorities had the capacity for this type of work. This reflects the way in which data and its analysis is implicated in shaping the discursive space of gender equality. We can also see here the twin poles of the arguments around managerialism in relation to equalities work. On one hand the interviewee is engaging with performance management at great depth in order to drive forward gender equality goals. So as Monro (2006) has suggested, we can see equalities framed in administrative, managerial terms rather than political, and how this can be constructive. However, the downside of this appears to be that the connections between different areas of work, and the structural analysis which would enable this, is left only in the understanding of individual workers, if at all.

Relatedly, although we might regard the requirement to explain and evidence working, and challenge assumptions as a positive development - it is also clearly a huge outlay of resources for a small, stretched team. Another interviewee also suggested that legislation could make some people complacent, providing a sense that equality was sorted and no longer required action. This reflects a post-feminist sensibility, experienced by this worker as undermining their use of the legislation as a positive tool. Just as Fraser (2013) has suggested the uncomfortable partial alignment of neoliberal and feminist agendas in recent 
decades, this ambivalence highlights the need for consideration of the implications different practices of enactment have in relation to equalities legislation.

Problematising the knowledge and understanding of equalities workers

My analysis suggests knowledge of equalities legislation can be viewed as one marker for the increasing significance of legislation in shaping local government gender equality work. The equality workers are the key actors in public sector implementation of this, as highlighted in another context by Callerstig (2014). Knowledge and understanding of gender equality as well as legislation was something I thus considered in relation to my data. It enables the workers to understand, communicate, translate and enact legislation and policy from national level into a local context, ideally stretching this to maximize gender equality outcomes. My comparative analysis of three councils evidenced different levels of knowledge in relation to gender equality. Although there were many points when interviewees displayed an extremely detailed knowledge and understanding of the issues at hand, there were also points, particularly in the late adopter council, where it appeared that the knowledge and understanding of gender reflected in the official documents and interviews, was limited and acted to shrink and fix the operationalization of gender equality in certain ways. For example, one of the workers in the late adopter council, even when prompted, did not appear to see gender equality working as extending to topics aside from violence against women and sex work. They also suggested they did not think gender equality would ever be achieved:

I think there'll always be inequality. And I think the fact that we're moving into this recession... isn't going to help matters. Because there'll be families out there that don't have a lot of money, there'll be mothers that think their only option is prostitution or 
whatever lap dancing or whatever else to get money for their families. (Fran, Senior Planning and Social Work Officer, Late Adopter Council)

Although this can be seen to reflect the interviewee's concern in relation to the impact of poverty and gender, I would suggest it is also illustrative of an individualised understanding of gender equality and sex work. The interviewee expanded on this perspective in relation to domestic violence, reflecting its occurrence as an individual rather than systemic dysfunction. I would argue this reflects a fairly limited understanding of gender, gender equality and the way in which inequalities are created or challenged, in contrast to Connell's multi-dimensional and dynamic account of it as structuring social relations. We might then question how effectively in such cases someone could interpret, develop or advocate for measures designed to improve gender equality, without a more structural understanding of the issues at play.

Given my interviewees represent those identified within the councils as most knowledgeable and responsible for equalities, in some cases this presents a worrying account of the level of understanding and expertise contained within their workforces. Of course many of the people I interviewed were extremely knowledgeable. However, with shrinking staff numbers and resources, including the drastic financial cuts faced by UK councils since 2010 , and small teams to begin with, each individual is significant. Knowledge of gender equality and of the relevant legislation has a significant impact on the way in which legislation is implemented in the context of local government, through policy and practice. This suggests a point of vulnerability in relation to gains in gender equality, legislative and otherwise. Given the complexity (and lack of guidance) around implementing the Equality Act, coupled with the reduced strength of the Public Sector Equality Dutyii, we must consider the implications this has for the scope and sustainability of work on gender equality, and equalities more broadly, going forward. 
Gender, protected characteristics and the Public Sector Equality Duty

Evidently, recent legislation has influenced the topics, priorities and approaches equalities workers' attend to. This has benefits and losses; for the (multi-dimensional) conception of gender and the extent to which this is dealt with (with other equalities strands) intersectionally (Crenshaw 1989). This is particularly significant in relation to the Public Sector Equality Duty, bringing together nine protected characteristics, and I suggest raises problems in relation to how work is prioritised and implemented.

Although recognition of a characteristic in legislation and policy is not the same as its being acted upon, there are positives for certain characteristics now being formally recognised in this way. As discussed, interviewees reflected positively on a newfound legitimacy for work on a wider range of areas, yet expressed the challenges in maintaining work with women. We might think of this in terms of axes of recognition (Fraser 1997), and a tool for claim making, and can also see this evident practically in the debates taking place amongst different interest groups in relation to the Equality Act (Squires and Hermanin 2012).

There are also areas which have now been brought together in legislation that would not previously have been considered in tandem, possibly encouraging of a more intersectional approach. However, it is also possible that the overt definition of, and distinction between, protected characteristics could work against attending to them in a structural, connected and intersectional manner. The codification of the strands within the 2010 Equality Act on the one hand reinforces their individuality as separate strands, while simultaneously bringing them together. This arguably represents conflicting logics within this legislative development, and mirrors some of the earlier arguments within the WLM around the costs and benefits of identity politics (Adams 1989, Harriss 1989). In the context of local government, it must now 
be asked how best we can recognise, weigh, and address different axes of inequality in a manner that attends to their intersection and interaction.

The theoretical potential of the Public Sector Equality Duty heightening conflict between strands was suggested by Judith Squires before it was enacted (Squires 2009), and more recently by Sandra Fredman (Fredman 2011). This is particularly important to consider given the issues raised by my interviewees with regard to how they sought, at times with difficulty, to use technical means to decide on and justify their work in relation to gender. The documents and interview data I collected largely did not appear to be addressing this issue explicitly or systematically, although admittedly early at this point. Only the enthusiastic follower council made explicit that equalities groups with the poorest outcomes were being prioritised. It is important that such rationales are made explicit as a key dimension in framing the type and scope of work on gender, and other equalities, that is enacted from legislation.

Problematically there did not seem to be guidance available to the councils, or to council staff within the documents examined, as to how you might go about making decisions between different courses of work. Or what you would do if an impact assessment revealed that some course of action deemed positive for one equality strand, would be detrimental for another. Although the Equality Act originally contained provisions for addressing multiple discrimination, this part of the Act was not brought into force by the government which inherited it (Squires and Hermanin 2012). The councils I studied did not show a consistent understanding or attention to the intersectionality of the strands. As discussed earlier, the councils varied in the extent to which their documents reflected the move to bring together the nine characteristics - with the enthusiastic follower reflecting this most clearly.

The question of how the equalities strands are understood and addressed in relation to each other in council practice, was not standardised at the point I collected my data. This 
exemplarises what is to play for in this discursive space; whether gender, and equalities work more broadly is operationalized to open up the potential for action, or 'shrunk' and 'fixed' in ways that limit it to specific topics. This connects closely to the significance of the knowledge and understanding of the equality workers, who are positioned at this point of interpretation and implementation. It remains to be seen whether this will change and/or become more standardised over time, yet as my analysis has suggested in relation to the Gender Equality Duty - this does not negate the significance of workers' knowledge, nor the potential interaction with the institutional histories of specific sites of local government. Going forward, the rationales and methods applied (or not) to bringing together and prioritise work on different equalities characteristics, seem worthwhile to attend to for those interested in the substantive enactment of equalities legislation.

\section{Conclusion}

Employing a comparative historical approach, this article has examined the significance of legislation for local government gender equality working in the UK - during the municipal feminist period of the 1980s, and three decades later in 2011. Using texts and interview data I revisited an underexplored facet of this significant phenomenon, finding that legislation was engaged with to differing degrees by the three councils during the municipal feminist period. This also evidenced the interpretive space around legislation in which workers have considerable influence, as seen in their different approaches. Comparing this to the data collected from the contemporary (2011) working of the same councils, I found legislation was increasingly significant, and argued the Gender Equality Duty has had a standardising effect on the work taking place. I also considered the recently introduced Public Sector Equality Duty, suggesting that the responsiveness of the councils' documents to this partly reflected their earlier positioning in relation to legislation, some 30 years earlier. 
I reflected on the detail, positive and negative, of how the council equalities workers experienced and employed legislation as part of the discursive politics of gender equality. This revealed it to be both generative and selective of work, as well as the manner in which this is carried out. Throughout, the role of knowledge - both of legislation and of gender equality itself - was shown as central to this enactment. There are several facets to this: the varying extents to which the equality workers displayed a structural and multi-dimensional understanding of gender; the increasingly technical nature of their work (driven in part by changing forms of management and legislative requirements); the increasing complexity and integration of multiple equalities strands; and the reduction in staffing and resources for equality work. These combine to place increasing emphasis on the significance of individual workers as actors in this space. This has implications for the quality and sustainability of the work that can take place on gender and other equalities. In particular I argued the issues of prioritising and connecting work on the different characteristics integrated within the Public Sector Equality Duty require further attention at this level.

My engagement with the workers suggests that despite its standardising influence, legislation does not negate the significance of the actors involved in its implementation. Looking at this over time has also suggested that institutional histories of gender equality work at local government level have implications for their responses to new legislation. The temporal comparison also enables us to observe more clearly the ambivalent role played by legislation in relation to understandings and action on gender equality. At different points in time it has served to legitimate and shape what takes place in positive ways, yet not uniformly. Although currently the existence of legislation can play a role in broader postfeminist discourses undermining such work, its implementation remains a space where knowledge and techniques of management are significant in defining what is problematised as requiring equality work. Evidently, gender equality legislation matters for what takes place at a local level, but is a frame with scope for interpretation, the process of which is worth attending to. 
Going forward with the Public Sector Equality Duty, we need to consider both what could practically support the strength of an intersectional approach to equalities being enacted in local government, and within this, a stretching as opposed to shrinking of the space for gender equality work. Shrinking council resources make it particularly difficult to see how these can be addressed at the level of practice. Without adequate resourcing, including knowledgeable staff, and time to develop a coherent and integrated approach to multiple equalities, the fate of gender equality work can appear somewhat dependent on chance and organisational history.

Acknowledgements

Many thanks to all the research participants who gave their valuable time to participate in this work. Thanks are also due to Jenny Parkes and Claire Maxwell for their generous advice, and to the anonymous reviewers for their constructive comments. I'd also like to gratefully thank Ben Fincham, Margaretta Jolly, Alison Phipps and Gillian Bendelow - for their wise guidance at different points in the process of carrying out this research.

\section{References}

Adams, M. L. (1989). 'There's No Place Like Home: On the Place of Identity in Feminist Politics.' Feminist Review 31(Spring): 22-33.

Allan, E. J. (2008). Policy Discourses, Gender and Education. London, Routledge.

Bashevkin, S. (2006). Tales of Two Cities: Women and Municipal Restructuring in London and Toronto. Vancouver, UBC Press.

Brown, W. (2003). 'Neo-liberalism and the End of Liberal Democracy.' Theory and Event 7.

Brownill, S. and S. Halford (1990). 'Understanding Women's involvement in local politics: How useful is a formal/informal dichotomy?' Political Geography Quarterly 9(4): 396-414. 
Bruegel, I. and H. Kean (1995). 'The moment of municipal feminism: gender and class in 1980s local government.' Critical Social Policy 15: 147-169.

Button, S. (1984). 'Women's Committees: A study of gender and local government policy making.' SAUS Working Paper 45.

Callerstig, A.-C. (2014). Making equality work: Ambiguities, conflicts and change agents in the implementation of equality policies in public sector organisations. Studies in Arts and Science, Linkoping Unicersity.

Cerwonka, A. and L. H. Malkki (2007). Improvising Theory: Process and Temporality in Ethnographic Fieldwork. Chicago, University of Chicago Press.

Chappell, L. (2013). 'Monolithic to Differentiated state'. The Oxford Handbook of Gender and Politics. G. Waylen, K. Celis, J. Kantola and S. L. Weldon. Oxford, Oxford University Press: 603-626.

Conley, H. and M. Page (2010). 'The Gender Equality Duty in Local Government: The Prospects for Integration.' Industrial Law Journal 39(3): 321-325.

Connell, R. W. (2002). Gender. Cambridge, Polity Press.

Coote, A. and P. Pattullo (1990). Power and Prejudice: Women and Politics. London, Weidenfeld and Nicolson.

Coyle, A. (1989). 'The Limits of Change: Local government and equal opportunities for women.' Public Administration 67(Spring): 39-50.

Crenshaw, K. (1989). 'Demarginalising the Intersection of Race and Sex: A Black Feminist Critique of Anti-Discrimination Doctrine, Feminist Theory, and Antiracist Politics.' University of Chicago Legal Forum 139: 139-168.

Edwards, J. (1988). 'Local Government Women's Committees.' Local Government Studies 14(4): 39-52.

Edwards, J. (1989). 'Women's Committees: A model for good local government?' Policy and Politics 17(3): 221-225.

Edwards, J. (1995). 'The Feminist Case for Local Self-government.' Local Government Studies 21(1): 82-98.

Franzway, S., et al. (1989). Staking a Claim: Feminism, bureaucracy and the state. Cambridge, Polity Press.

Fraser, N. (1997). Justice Interruptus. London, Routledge.

Fraser, N. (2013). Fortunes of Feminism. London, Verso. 
Fredman, S. (2011). 'The Public Sector Equality Duty.' Industrial Law Journal 40(4): 405-427.

Gibson, J. (1992). 'British local government finance under the conservatives.' Local Government Studies 18(4): 55-78.

Gill, R. (2007). Gender and the media. Cambridge, Polity Press.

Goss, S. (1984). 'Women's Initiatives in Local Government '. Local Socialism? Labour Councils and New Left Alternatives. M. Boddy and C. Fudge. Basingstoke, Macmillan: 109-132.

Halford, S. (1990). Local Politics, Feminism and the Local State: Women's Initiatives in British Local Government in the 1980s. Graduate School of Arts and Social Studies. Falmer, University of Sussex. PhD.

Halford, S. (1992). 'Feminist change in a patriarchal organisation: the experience of women's initiatives in local government and implications for feminist perspectives on state institutions'. Gender and Bureaucracy. M. Savage and A. Witz. Oxford, Blackwell: 155-185.

Halford, S. and P. Leonard (2001). Gender, Power and Organisations. London, Palgrave.

Hand, J., et al. (2012). 'Unification, simplification, amplification? An analysis of aspects of the British Equality Act 2010.' Commonwealth Law Bulletin 38(3): 509-528.

Harriss, K. (1989). 'New Alliances: Socialist-Feminism in the Eighties.' Feminist Review 31(Spring): 34-54.

Holli, A. M., et al. (2006). 'Quota trouble: Talking about gender quotas in finnish local politics.' International Feminist Journal of Politics 8(2): 169-193.

Kantola, J. (2006). Feminists Theorize the State. Basingstoke, Palgrave Macmillan.

Kantola, J. and J. Squires (2012). 'From state feminism to market feminism?' International Political Science Review 33(4): 382-400.

Leach, R. and N. Barnett (1997). 'The new public management and the local government review.' Local Government Studies 23(3): 39-55.

Leach, S. (2010). 'The Labour Government's Local Government Agenda 1997-2009: The Impact on Member-Officer Relationships.' Local Government Studies 36(3): 323-339.

Leach, S. and H. Davis (1990). 'Impact of the abolition of the metropolitan county councils.' Local Government Studies 16(3): 1-11.

Lombardo, E., et al. (2009). 'Conclusions: A critical understanding of the discursive politics of gender equality'. The Discursive Politics of Gender Equality. E. Lombardo, P. Meier and M. Verloo. Abingdon, Routledge: 186-203. 
Lovenduski, J. (1989). 'Implementing Equal Opportunities in the 1980s: An Overview.' Public Administration 67(Spring): 7-18.

Lovenduski, J. (2007). 'Unfinished Business: Equality Policy and the Changing Context of State Feminism in Great Britain'. Changing State Feminism. J. Outshoorn and J. Kantola. Basingstoke, Palgrave Macmillian: 144-163

Lovenduski, J. and V. Randall (1993). Contemporary Feminist Politics: Women and Power in Britain. Oxford, Oxford University Press.

MacKay, F. (2008). 'The state of women's movement/s in Britain: ambiguity, complexity and challenges from the periphery'. Women's Movements: Flourishing or in abeyance? S. Grey and M. Sawer. Abingdon, Routledge: 17-32.

Mazur, A. and D. M. Stetson (1995). 'Conclusion: The Case for State Feminism'. Comparative State Feminism. A. Mazur and D. M. Stetson. London, Sage: 272-291.

McBride, D. E. and A. G. Mazur (2010). The Politics of State Feminism. Philadelphia, Temple University Press.

McLaughlin, E. (2007). 'From Negative to Positive Equality Duties: The Development and Constitutionalisation of Equality Provisions in the UK.' Social Policy \& Society 6(1): 111-121.

McRobbie, A. (2004). 'Post-feminism and Popular Culture.' Feminist Media Studies 4(3): 255264.

McRobbie, A. (2007). 'Top Girls? Young women and the post-feminist sexual contract.' Cultural Studies 21(4-5): 718-737.

McRobbie, A. (2009). The Aftermath of Feminism: Gender, Culture and Social Change. London, Sage.

Monro, S. (2006). 'Evaluating Local Government Equalities Work: The Case of Sexualities Initiatives in the UK.' Local Government Studies 32(1): 19-39.

Newman, J. (2000). 'Beyond the New Public Management? Modernizing Public Services'. New Managerialism, New Welfare? J. Clarke, S. Gewirtz and E. McLaughlin. London, Sage: 45-61.

Parker, I. (1992). Discourse Dynamics: Critical analysis for social and individual psychology London, Routledge.

Randall, V. (1998). 'Gender and power: women engage the state'. Gender, Politics and the State. V. Randall and G. Waylen. London, Routledge: 185-205. 
Richardson, D. and S. Monro (2013). 'Public Duty and Private Prejudice: Sexualities Equalities and Local Government.' The Sociological Review 61(4): 131-152.

Rowbotham, S. (1979). 'The Women's Movement and Organizing for Socialism'. Beyond the Fragments. S. Rowbotham, L. Segal and H. Rowbotham. London, Merlin Press: 21-155.

Rowbotham, S. (1996). 'Introduction: Mapping the Women's Movement'. Mapping the Women's Movement. M. Threlfall. London, Verso.

Squires, J. (2009). 'Intersecting Inequalities: Britain's Equality Review.' International Feminist Journal of Politics 11(4): 496-512.

Squires, J. and C. Hermanin (2012). 'Institutionalizing Intersectionality in the 'Big Three': The Changing Equality Framework in France, Germany and Britain'. Institutionalizing intersectionality, the changing nature of European equality regimes A. Krizsan, H. Skjeie and J. squires. Basingstoke, Palgrave Macmillian: 89-118.

Stokes, W. (1998). 'Feminist democracy: The case for women's committees.' Contemporary Politics 4(1): 23-37.

Swann, E. and S. Fox (2010). 'Playing the Game: Strategies of Resistance and Co-optation in Diversity Work.' Gender, Work and Organisation 17(5): 567-589.

Thorsen, D. E. and A. Lie (2006). 'What is Neoliberalism?'.

Travers, T. (1990). 'London After Abolition.' Local Government Studies 16(3): 105-116.

Walkerdine, V. (2003). 'Reclassifying Upward Mobility: femininity and the neoliberal subject.' Gender and Education 15: 217-248.

Watson, S. (1991). 'Femocratic feminisms.' The Sociological Review 39(1): 186-204.

Witz, A. and M. Savage (1991). 'The gender of organisations.' The Sociological Review 39(1): 3-62.

\footnotetext{
${ }^{i}$ The general duties required public bodies to have due regard in carrying out their functions to: eliminate discrimination and harassment on the grounds of sex, and promote equality of opportunity between women and men. The specific duties required public bodies to: prepare and publish a gender equality scheme, showing how it will meet its duties and setting out its gender equality objectives; consider the need to include objectives to address the gender pay gap; gather and use information on how the public authority's policies and practices affect gender equality in the workforce and in the delivery of services; consult stakeholders and take into account relevant information to determine its gender equality objectives; and assess the impact of current and proposed policies and practices on gender equality. It also required them to implement the actions set out in the scheme within three years, report on the scheme every year, and review the scheme at least every three years.
} 
ii The specific duties for public bodies are now less extensive, being to: publish information annually to demonstrate its compliance with the general equality duty, and prepare and publish one or more objectives that it thinks it needs to achieve to further any of the aims of the general equality duty which must be specific and measurable. 